\begin{tabular}{|c|c|c|}
\hline 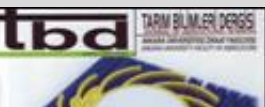 & $\begin{array}{l}\text { Tarım Bilimleri Dergisi } \\
\text { Tar. Bil. Der. }\end{array}$ & Journal of Agricultural Sciences \\
\hline & $\begin{array}{c}\text { Dergi web sayfası: } \\
\text { www.agri.ankara.edu.tr/dergi }\end{array}$ & $\begin{array}{c}\text { Journal homepage: } \\
\text { www.agri.ankara.edu.tr/journal }\end{array}$ \\
\hline
\end{tabular}

\title{
The Relationships Between Propolis Collecting Capability and Morphometric Features of Some Honey Bee Races and Ecotypes in Anatolia
}

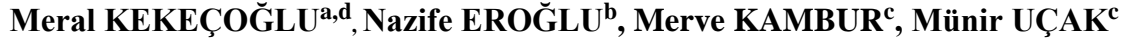

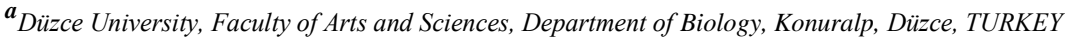

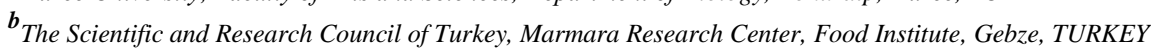

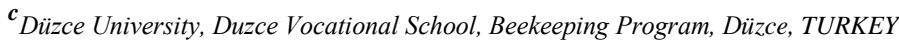

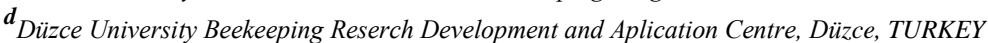

\section{ARTICLE INFO}

Research Article

Corresponding Author: Meral KEKEÇOĞLU, E-mail: meralkekecoglu@ duzce.edu.tr, Tel: +90 (380) $5421100 / 1032$

Received: 06 August 2018, Received in Revised Form: 06 November 2018, Accepted: 22 December 2018

\section{AUTHORS ORCID ID}

(Meral KEKEÇOĞLU: 0000-0002-2564-8343), (Nazife EROĞLU: 0000-0002-8618-2583), (Merve KAMBUR: 0000-00019658-6584), (Münir UÇAK: 0000-0003-1538-6711)

\begin{abstract}
Propolis collecting capacity of the honey bee race, Apis mellifera L., distributed across Anatolia and Thrace regions of Turkey was investigated and correlated with morphometric characteristics. Thus, the propolis collecting behaviour of honey bee races and ecotypes naturally have been in Turkey, Apis mellifera caucasica, Apis mellifera carnica, Apis mellifera syriaca and Yığılca and Muğla ecotype of Apis mellifera anatoliaca were monitored. The mean yield of annual propolis was recorded as the following; Ylğılca ecotype (111.6 $\pm 27.5 \mathrm{~g}$ colony) A. m. caucasica (104 $\pm 20.7 \mathrm{~g}$ colony), Muğla ecotype ( $103 \pm 34 \mathrm{~g}$ colony), $A$. m. carnica ( $91.16 \pm 17.6 \mathrm{~g}$ colony), and A. $m$. syriaca $(74 \pm 6.4$ $\mathrm{g}$ colony) in descending order. The highest propolis collecting activity was recorded for the Yiğılca ecotype of $A$. $m$. anatoliaca and A. m. caucasica. Morphological features
\end{abstract}

of honey bee samples were evaluated by classic morphometric technique to correlate propolis collecting capability and morphological features. Morphometric results of the present study showed that the largest wing and leg lengths belonged to Yığılca ecotype of A. m. anatoliaca and A. m. caucasica. Furthermore, Pearson correlation showed a significant relationship between some morphometric characteristics including the proboscis and mandibular sections, wing length (WL), wing width (WW), femur length (FL), tibia length (TL), basitarsus length (BL), basitarsus width $(\mathrm{BW})$, and propolis collecting capability $(\mathrm{P}<0.05)$. Therefore, it seems that the enlargement of certain morphological properties with genetic tendency of the honey bee races and ecotypes, primarily the legs and wings, can lead to better propolis collecting capability.

Keywords: Propolis harvesting; Morphometric characteristics; Correlation; Apis mellifera L.; Anatolia

\section{Introduction}

(C) Ankara Üniversitesi Ziraat Fakültesi

Morphological differences in honey bee races have led to the most distinctive differences that are associated with pollen and propolis collecting behaviour (Winston 1991). The mouthparts, plumose hairs, and 
broadened hind legs are important morphological characters, especially for propolis collection behaviour (Michener 1974). The hairy coverings of the body, which may consist of branched and unbranched hairy setae, and appendages provide collecting surfaces upon which pollen grains are retained until the bee delivers them to the hive (Goodman 2003). Mouthparts of the bee, including mandibles and the maxillae and tongue (proboscis), are essential features to scrape over any surface, while each hind leg of the worker bee is adapted for holding and transporting of these grains (Goodman 2003). The outer surface of the tibia is characterized by an elongated depression with long hairs covering a receptacle or basket (corbicula) which is a characteristic feature of the Apinae (Winston \& Michener 1977; Michener et al 1978). A concave region of the corbicula, formed by exceptional modification of the hind leg, is used as an anchor for pollen and propolis delivering functions (Hodges 1967). The current paradigm is the belief that corbicula initially serve to carry sticky propolis back to the nest as a building material, then the other leg modification of the hind leg occurred for pollen collection (Winston \& Michener 1977; Michener et al 1978). Propolis, pollen and nectar collecting behaviours of honey bees have been shown by many studies to correlated with external structures consisting of brushes on the hind legs, corbiculum on hind tibia (Thorp 2000), and the mouthparts and proboscis (Michener et al 1978; Ajao et al 2014).

The amount and quantity of propolis collected by honey bees are related to botanical sources, season, year, propolis collecting techniques and even genetic origin of honey bee races (Mobus 1972; Ghisalberti 1979; Crane 1990). However, there are a few studies indicating that propolis collecting capability is also correlated with certain honey bee races which possess better ability to collect propolis (Ghisalberti 1979; Crane 1990). Some honey bee races such as Apis dorsata, Apis florea, and Apis cerana do not exhibit propolis collecting behaviour (Wollenweber \& Buchmann 1997). Africanized honey bee races have lead to huge success in Brazil (Manrique \& Soares 2002), compared to European races of A. mellifera for propolis collecting (Garcia et al 2013). Western honey bee races are known as having the more propolis collecting capacity than others (Ruttner 1988b). Grey Caucasian Mountain ecotype of A. m. caucasica honey bees was reported to collect much more propolis than A. m. ligustica and Far East Dark Forest bees (Thorp 2000). A. m. carnica was reported to use propolis rather than bees wax inside the hive (Ghisalberti 1979). The main propolis production of per colony was reported to be 10-300 g for per year (Ochi 1981; Andrich et al 1987). One of the earliest studies reported that annual propolis yield ranged from a minimum of $50 \mathrm{~g}$ to a maximum of $600 \mathrm{~g}$ for different honey bee races (Ghisalberti 1979).

Because of the excessive use of propolis by Apis mellifera iberica and Apis mellifera intermissa, these bees can survive winter temperatures at $-45{ }^{\circ} \mathrm{C}$ and have adapted to climate with temperature extremes (Ruttner 1988a). And also they are known to be susceptible to brood diseases, which could be a further reason for slather use of propolis (Ruttner 1988b).

The objective of the present study was to evaluate the propolis collecting capability of indigenous honey bees, A. m. caucasica, A. m. syriaca, A. m. carnica, Yı̆̆llca and Muğla ecotypes of A. m. anatoliaca, distributed around Turkey. These races were under controlled conditions in Ankara, Middle Anatolia, Turkey. Additionally, the aim was also to investigate the possible relationship between morphometric features (forewing, hind leg, mandible and proboscis dimensions) and the propolis collecting capability of these honeybee races and ecotypes. Few studies have been conducted thus far, on propolis collecting potential of different honey bees races, and there has been no study reported in the literature focusing on the relationship between phenotypic properties and propolis collecting to date.

\section{Material and Methods}

\subsection{Propolis collecting}

Bee colonies with pure queens, the same aged and colony strenght, eight to nine adult frames, were procured from an original and isolated locations for the examination of propolis collecting behaviour in 2015. Colonies lived in their original locations were obtained for experiment. Locations of the races and ecotypes as follows; Muğla ecotype from Muğla province, Yı̆̆ılca ecotype from Yı̆̆ılca district of Düzce province, A. $m$. carnica from Kofçaz district of Kırklareli, A. $m$. syriaca from Hatay province, A. $m$. caucasica from Artvin province. Ten colonies were selected for each race and ecotypes. All colonies examined in the 
present study were maintained under controlled conditions in the same apiary in Central Anatolia, Turkey, between April-July 2015. Propolis traps were inserted on the top of the hives according to the methods of Şahinler \& Yücel (2016) in early spring. Hand collection method was conducted monthly from April to July, 2015. Raw propolis samples were acquired from traps and sorted in order to evaluate propolis harvesting capacity regarding honey bee race. Each trap was initially weighed and subtracted from final gross weight, and then recorded.

\subsection{Morphometric analyze of Honey bee}

Worker bees were collected from all colonies including three different honey bee races A. m. caucasica, A. $m$. carnica, $A$. $m$. syriaca and two ecotypes of $A$. $m$. anatoliaca to investigate the relationship between propolis collecting capacity and morphometric measurements of honey bees. Dissection of wings, hind legs, mandible and proboscis were executed (Kekeçoğlu \& Soysal 2010).

Preparations of body segments, wing length (WL), wing width (WW), femur length (FL), tibia length (TL), basitarsus length (BL), basitarsus width (BW), whole leg length (WLL), proboscis length (PL) were performed by slight modification according to Kekeçoğlu (2010). All slides were photographed and then measured with a Nikon SMZ745T stereomicroscope equipped with an oculars digital camera system of 1X (except proboscis which required an ocular of $3 \mathrm{X}$ ), and then digitalized with de novo Bs200Pro (BAB Imaging systems, BAB Ltd 1993) (Figure 1a, b, c, d).
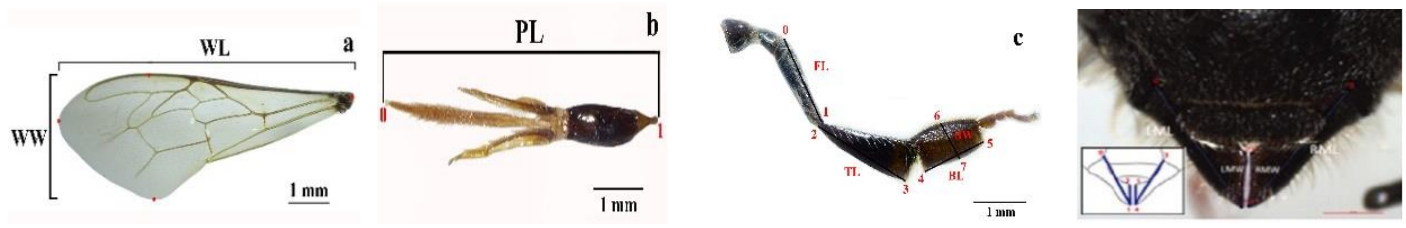

Figure 1- Wing (a), proboscis (b), leg (c) and mandibula (d) morphometric characters of honey bee

\subsection{Statistical analysis}

Statistical analysis was utilized by using SPSS.15.0 (2005) software. Discriminant function analysis (DFA) was used to classify the colonies and to check the probability that each colony had been correctly classified. ANOVA Posthoc-Tukey Test was performed to explain morphological characteristics which had a particular effect on races and ecotypes. Finally, Pearson's correlation method was applied to investigate any potential relationship between propolis collecting capacity and morphometric measurements of honey bees.

\section{Results and Discussion}

In this study, propolis collecting capacity of three races (A. m. caucasica, A. m. syriaca, and A. m. carnica) and two ecotypes (Yı̆̆ılca, Muğla ecotypes) of $A$. $m$. anatoliaca in the same apiary were compared during the same season to evaluate propolis collection capability. The amount of propolis collected by each honeybee races were presented in Figure 2. The mean yields were as follows: Y1 1 1lca ecotype: 111.6 27.5 g colony; A. m. caucasica: $104 \pm 20.7$ g colony; Muğla ecotype: $103 \pm 34$ g colony; A. m. carnica: $91.16 \pm 17.6$ g colony; and A. m. syriaca: $74 \pm 6.4$ g colony.

To investigate the relationship between morphometric pattern of honey bees and propolis collecting capacity, eleven morphometric dimension (WL, WW, PL, FL, BL, TL, BW, LML, RML LMW, and RMW) were evaluated. A. m. caucasica was found to have the largest size of the WL, TL, LMW, and RMW, while the Yiğılca ecotype of $A$. m. anatoliaca had the greatest length of the other 5 characters (WW, PL, FL, BL, BW, LML, RML) (Table 1). According to results of ANOVA, notable significances were found between group variances for $\mathrm{WL}(\mathrm{F}=49.624, \mathrm{P}<0.00)$, WW $(\mathrm{F}=26.224, \mathrm{P}<0.00)$, $\mathrm{FL}(\mathrm{F}=8.163, \mathrm{P}<0.00), \mathrm{TL}(\mathrm{F}=$ 11.055, $\mathrm{P}<0.00), \mathrm{BU}(\mathrm{F}=24.424, \mathrm{P}<0.00), \mathrm{BW}(\mathrm{F}=13.058, \mathrm{P}<0.00)$ and $\mathrm{PL}(\mathrm{F}=6.919, \mathrm{P}<0.00)$ charecters. 
The PostHoc-Tukey analysis was used to reveal which morphometric characters (WL, WW, FL, TL, BL, BW and PL) differentated honey bee groups. It was monitored that A. m. caucasica and Yiğılca ecotype of A. $m$. anatoliaca have statistically similar metric features $(\mathrm{P}>0.05)$. Therefore, They can be assessed together within the similar group for BL and BW, WL, WW, BL and BW characters. FL and TL variables were significantly different between the groups: $A$. $m$. caucasica- $A$. $m$. carnica (FL: $\mathrm{P}<0.13$, TL: $\mathrm{P}<0.000$, PL), A. m. caucasica- A. m. syriaca (FL: $\mathrm{P}<0.000$, TL: $\mathrm{P}<0.000$ ), Yı̆̆ılca ecotype-Muğla ecotype (FL: $\mathrm{P}<0.000$, TL: $\mathrm{P}<0.031)$.

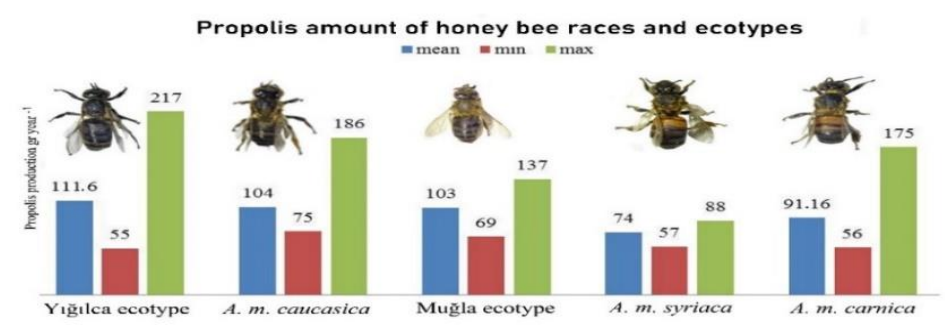

Figure 2- The mean, minimum and maximum propolis amount of three different races and two ecotypes (gr), April-July 2010, Ankara, Turkey

Table 1- The mean and standard deviation of some morphometric characters of honey bee races

\begin{tabular}{|c|c|c|c|c|c|c|}
\hline \multirow{2}{*}{\multicolumn{2}{|c|}{$\begin{array}{l}\text { Morphometric } \\
\text { characters } \\
(\mathrm{mm})\end{array}$}} & \multicolumn{5}{|c|}{$\begin{array}{l}\text { Honey bee race and ecotypes } \\
\text { (mean }+ \text { standard deviation) }\end{array}$} \\
\hline & & \multirow{2}{*}{$\begin{array}{l}\text { Yiğllca ecotype } \\
(n=30)\end{array}$} & \multirow{2}{*}{$\begin{array}{l}\text { A. m. caucasica } \\
(n=45)\end{array}$} & \multirow{2}{*}{$\begin{array}{l}\begin{array}{l}\text { Muğla ecotype } \\
(n=30)\end{array} \\
9.39 \pm 0.10^{\mathrm{a}}\end{array}$} & \multirow{2}{*}{$\begin{array}{l}\begin{array}{l}\text { A. m. syriaca } \\
(n=60)\end{array} \\
9.39 \pm 0.23^{\mathrm{a}}\end{array}$} & \multirow{2}{*}{$\begin{array}{l}\begin{array}{l}\text { A. m. carnica } \\
(n=45)\end{array} \\
9.68 \pm 0.19^{\mathrm{b}}\end{array}$} \\
\hline Wing & WL & & & & & \\
\hline & WW & $3.34 \pm 0.06^{\mathrm{c}}$ & $3.28 \pm 0.08^{\mathrm{b}}$ & $3.17 \pm 0.09^{\mathrm{a}}$ & $3.14 \pm 0.11^{\mathrm{a}}$ & $3.24 \pm 0.07^{\mathrm{b}}$ \\
\hline \multirow[t]{2}{*}{ Proboscis } & PL & $6.90 \pm 0.24^{\mathrm{b}}$ & $6.67 \pm 0.33^{\mathrm{a}}$ & $6.68 \pm 0.17^{\mathrm{a}}$ & $6.56 \pm 0.17^{\mathrm{a}}$ & $6.51 \pm 0.40^{\mathrm{a}}$ \\
\hline & FL & $3.33 \pm 0.07^{\mathrm{c}}$ & $3.32 \pm 0.13^{\mathrm{b}}$ & $3.26 \pm 0.10^{\mathrm{ab}}$ & $3.22 \pm 0.10^{\mathrm{a}}$ & $3.25 \pm 0.12^{\mathrm{ab}}$ \\
\hline \multirow{3}{*}{ Leg } & $\mathrm{TL}$ & $3.27 \pm 0.10^{\mathrm{bc}}$ & $3.31 \pm 0.12^{\mathrm{c}}$ & $3.18 \pm 0.10^{\mathrm{a}}$ & $3.18 \pm 0.10^{\mathrm{a}}$ & $3.20 \pm 0.12^{\mathrm{ab}}$ \\
\hline & $\mathrm{BL}$ & $2.15 \pm 0.09^{c}$ & $2.14 \pm 0.10^{\mathrm{c}}$ & $2.02 \pm 0.08^{\mathrm{ab}}$ & $1.98 \pm 0.09^{\mathrm{a}}$ & $2.06 \pm 0.08^{\mathrm{b}}$ \\
\hline & BW & $1.28 \pm 0.06^{\mathrm{b}}$ & $1.25 \pm 0.06^{\mathrm{b}}$ & $1.19 \pm 0.05^{\mathrm{a}}$ & $1.20 \pm 0.05^{\mathrm{a}}$ & $1.20 \pm 0.05^{\mathrm{a}}$ \\
\hline \multirow{4}{*}{ Mandible } & LML & $4.68 \pm 0.08^{\mathrm{a}}$ & $4.56 \pm 0.17^{\mathrm{a}}$ & $4.45 \pm 0.17^{\mathrm{a}}$ & $4.45 \pm 0.16^{\mathrm{a}}$ & $4.41 \pm 0.13^{\mathrm{a}}$ \\
\hline & LMW & $1.69 \pm 0.04^{\mathrm{a}}$ & $1.71 \pm 0.07^{\mathrm{a}}$ & $1.61 \pm 0.09^{\mathrm{a}}$ & $1.65 \pm 0.07^{\mathrm{a}}$ & $1.69 \pm 0.08^{\mathrm{a}}$ \\
\hline & RML & $4.60 \pm 0.08^{\mathrm{a}}$ & $4.47 \pm 0.15^{\mathrm{a}}$ & $4.36 \pm 0.19^{\mathrm{a}}$ & $4.43 \pm 0.16^{\mathrm{a}}$ & $4.31 \pm 0.15^{\mathrm{a}}$ \\
\hline & RMW & $1.69 \pm 0.05^{\mathrm{a}}$ & $1.70 \pm 0.06^{\mathrm{a}}$ & $1.60 \pm 0.07^{\mathrm{a}}$ & $1.63 \pm 0.09^{\mathrm{a}}$ & $1.65 \pm 0.18^{\mathrm{a}}$ \\
\hline
\end{tabular}

FL, femur length; WL, wing length; WW, wing weight; PL, proboscis length; TL, tibia length; BL, basitarsus length; BW, basitarsus width; LL, whole length of leg; LML, left mandibula length; LMW, left mandibula width; RML, right mandibula length; RMW, right mandibula width

Pearson Correlation analysis provided valuable insight to the relationship between morphometric characters and propolis collecting capabilities. The relationship between the length and width of the wings (WL, WW) and propolis collecting capability were found significant statistically $(\mathrm{P} \leq 0.008,0.015)$. Furthermore, the correlation between length of the leg (FL, TL, BL, BW) and propolis collecting capability were great importance respectively; $\mathrm{P} \leq 0.011,0.002,0.014$ and 0.023 . There was a positive correlation between all morphometric features of leg and wing and mean propolis yield, except for proboscis length and mandibula width and length (Table 2).

Table 2- The correlation between some morphometric characters of honey bees and propolis collecting capacity

\begin{tabular}{|c|c|c|c|c|c|c|c|c|c|c|c|c|}
\hline Correlations & $\begin{array}{l}\text { Morph. } \\
\text { features }\end{array}$ & $W L$ & $W W$ & $P L$ & $F L$ & $T L$ & $B L$ & $B W$ & $L M L$ & $L M W$ & $R M L$ & $R M W$ \\
\hline \multirow{2}{*}{$\begin{array}{l}\text { Propolis } \\
\text { Production } \\
\text { (gr) }\end{array}$} & $\begin{array}{l}\text { Pearson } \\
\text { Correlation }\end{array}$ & $0.963^{* *}$ & $0.945^{*}$ & 0.821 & $0.965^{*}$ & $0.978 * *$ & $0.977 * *$ & $0.927 *$ & 0.702 & 0.764 & 0.473 & 0.467 \\
\hline & $\begin{array}{l}\text { Sig. } \\
\text { (2-tailed) }\end{array}$ & 0.008 & 0.015 & 0.089 & 0.011 & 0.002 & 0.014 & 0.023 & 0.187 & 0.167 & 0.421 & 0.428 \\
\hline
\end{tabular}

*, correlation is significant at the 0.05 level (2-tailed); **, correlation is significant at the 0.01 level (2- tailed) ${ }^{*}$ FL, femur length; WL, wing length; WW, wing weight; PL, proboscis length; TL, tibia length; BL, basitarsus length; BW, basitarsus width; LML, left mandibula length; LMW, left mandibula width; RML, right mandibula length; RMW, right mandibula width 
Morphological biodiversity and foraging behaviours are under the influence of geographic conditions, plant diversity and genetic structure (Michener 2007). As one of the foraging behaviour, propolis collecting performance also closely related with acquired morphologic features (Garcia et al 2013). Mobus (1972) reported that $A$. m. caucasica known to excessive use of propolis has higher propolis collecting ability than other races examined. Silici \& Kutluca (2005), Şahinler \& Gül (2005) found that Anatolian honey bee (A. m. anatoliaca) has better propolis collecting capability than Italian (A. m. ligustica), Caucasian (A. $m$. caucasica), and Carniolan (A. m. carnica) honey bees in the conditions of Hatay province, where located on the Meditearranean Region. Whereas Kutluca (2003) reported the highest mean propolis yield from Carniolan bee, followed by the Anatolian and Caucasian in Erzurum (Eastern Anatolia). In a controlled apiary in Erzurum, Turkey, Kutluca (2003) measured a mean propolis yield of $11.40 \pm 2.19 \mathrm{~g}$ colony, $19.20 \pm 5.49 \mathrm{~g}$ colony and $15.30 \pm 5.30 \mathrm{~g}$ colony in Caucasian, Carniolan and Anatolian genotypes, respectively. Sahinler \& Gül, (2005) studied Italian, Anatolian, Caucasican, and Carniolan honey bees in the Hatay province of Turkey and reported that the highest amount of propolis yield was produced by Anatolian honey bees under the same conditions, namely displaying $39.67 \mathrm{~g}$ colony, while Caucasican, Carniolan, and Italian honey bees produced 27.34, 29.63 and $26.12 \mathrm{~g}$ colony respectively. According to our

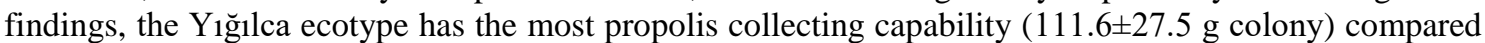
to other honeybee races situated in Anatolia under the same environmental conditions in Ankara, Central Anatolia. The other performances are as follows in descending sort; A. m. caucasica, A. m. carnica, Muğla ecotype and A. $m$. syriaca (Figure 2). The Black Sea region consists of a temperate rainforests characterized by, damp and forested mountains also steeps and hilly grassland while the Anatolian Plateau has a various climate conditions such as hot season, dry summers, long winters, heavy snow fall (Metz 1996; Çakmak 2005). The outcome of this study also showed that "northern honeybee populations (A. m. carnica, Ylğılca ecotype, A. m. caucasica)" have better propolis collecting ability than that of southern honeybee populations (Muğla ecotype, A. m. syriaca) (Figure 2) not only in their original locations in the Marmara and Black Sea regions, but also in the Middle Anatolia. Moreover, biochemical compositions of propolis may vary depending on flora, geographic conditions and honeybee races likewise A. m. caucasica has more antibacterial propolis compaunds than that of A. m. carnica and A. m. anatoliaca races (Silici \&Kutluca 2005).

Successful adaptations of races to the varied habitats induce for specialization in behavioural and phenotypic characteristics for many taxa (Hepburn \& Radloff 1997; Fletcher 1978). Therefore, morphometric characters, namely body size, tongue length, and color and foraging behaviour, propolis and pollen collecting can be vary among to honey bee races (Buttel-Reepen 1906; Alpatov 1929; Skorikov 1929; Maa 1953; Adam 1983). It was indicated that honeybees forage and transport pollen and propolis through externally specialized scrub and corbicula structures (Thorp 1979; Medved et al 2014). Calderone \& Page (1988) reported that the differences in the pollen-collecting performances between two artifically selected strains derived from the consequence of phenotypic differences of them. Our findings showed that the segments of the wing, leg and proboscis have statistically significant and high level morphometric variations in northern populations than that of southern populations. It was detected that northern honeybee populations (including Yığılca ecotype of $A . m$. anatoliaca and A. $\mathrm{m}$. caucasica) have more propolis collecting capabilities than that of southern populations (Figure 2). It is revealed that the propolis collection capacity can vary between the ecotypes of the same races as far as it is at the subspecific level. Moreover, positive significant correlations were observed between propolis collecting and six morphometric character measurements (WL, WW, FL, TL, BL and BW) (Table 2). Black Sea Region has rainy climate, dense forest and short vegetation period unlike the other regions. Regional differentiations and significant relations indicated that as the body segments developed, honey bees enable to carry more propolis and other forage products. This results emphasized that longer and stronger or shorter body segments may occur depending on adaptation to habitat as an advantage and propolis collection activity is closely related to body segments as well as genetic make up.

\section{Conclusions}

Results of the present study show that different honey bee races and their ecotypes have the distinctive propolis collecting capability. Therefore, morphometric differences between honey bee races also ecotypes 
can be used as an advantage by beekeepers, depending on what traits are in their best interest under the appropriate habitat and environmental conditions.

\section{Acknowledgements}

This study was fully supported by The Scientific and Technological Research Council of Turkey (TÜBITAK), BIDEB-2232 Project No: 113C036, Institution Code: 5134103 under the name of "Investigation of important honey bee, Apis mellifera L. (Hymenoptera, Apidae), races and ecotypes in Turkey considering propolis collection capacity and chemical characterization of Turkish propolis".

\section{References}

Adam B (1983). In search of the best strains of honey bee. Dadant Sons, Hamilton Illons, N. Bee Books, West Yorkshire

Ajao A M, Oladimeji Y U, Babatundel S K \& Obembe A (2014). Differential morphometric patterns of Apis mellifera and adaptation to climatic variations Global. Journal of Bioscience and Biotechnology 3(1): 34-40

Alpatov W W (1929). Biometrical studies on variation and races of the honey bee (Apis mellifera L.). The Quarterly Review of Biology 4(1): 1-58

Andrich G, Fiorentini R \& Consiglieri A (1987). [Characteristics of some samples of propolis from the Ligurian Coast] Caratteristiche di alcuni tipi di propoli della Riviera Ligure. Citta delle Api 28: 30-38

BAB Imaging Systems, BAB Ltd. (1993). Model Bs200Pro. www.bab.com.tr 27.12.2016

Buttel-Reepen H V (1906). Apistica. Beiträge zur Systematik, Biologie, sowie zur geschichtlichen und geographischen Verbreitung der Honigbiene (Apis mellifera L.) ihrer Varietaten und der ubrigen Apis-Arten. Mitteilungen Zoologisches Museum Berlin pp. 117-201

Calderone N W \& Page Jr R E (1988). Genotypic variability in age polyethism and task specialization in the honey bee, Apis mellifera (Hymenoptera: Apidae). Behavioral Ecology and Sociobiology 22(1): 17-25

Crane E (1990). Bees and beekeeping: science, practice and world resources. Heinemann Newnes pp. 117-142

Çakmak I (2005). The biodiversity of honey bee races in Turkey. In 3rd European Congress on Social Insects 22-27 Agust, 2005: 58

Fletcher D J C (1978). The African bee, Apis mellifera adansonii, in Africa. Annual Review of Entomology 23: 151171

Garcia R C, Oliveira N T E D, Camargo S C, Pires B G, Oliveira C A L D, Teixeira R D A \& Pickler M A (2013). Honey and propolis collecting, hygiene and defense behaviors of two generations of Africanized honey bees. Scientia Agricola 70(2): 74-81

Ghisalberti E L (1979). Propolis: a Review. Bee World 60(2): 59-84

Goodman L (2003). Form and Function in the Honey Bee, (completed and edited by Richard Cooter and Pamela Munn). International Bee Research Association, Cardiff, U.K. pp. 70-119

Hepburn H R \& Radloff S E (1997). Honeybees of Africa. Springer, Berlin, pp. 158

Hodges D (1967). The function of the 'Single hair'on the floor of the honey bees corbicula. Bee World 48(2): 58-62

Kekeçoğlu M (2010). Honeybee biodiversity in Western Black Sea and evidence for a new honey bee ecotype in Yı̆ğlca Province. $B \dot{I B} A D$ 3(1): 73-78

Kekeçoğlu M \& Soysal M I (2010). Genetic diversity of bee ecotypes in Turkey and evidence for geographical differences. Romanian Biotechnological Letters 15(5): 5646-5653 
Kutluca S (2003). The effects of propolis collecting methods on the colony performance and chemical properties of propolis. Atatürk University Graduate School of Natural and Applied Sciences Department of Animal Sciences, Erzurum, Turkey pp. 70-73

Maa T C (1953). An inquiry into the systematics of the tribus Apidini or honey bees (Hymenoptera). Treubia 2(3): 525640

Manrique A J \& Soares A E E (2002). Start of africanized honey bee selection program for increased propolis collecting and its effect on honey production. Interciencia 27(6): 312-316

Medved V, Huang Z Y \& Popadić A (2014). Ubx promotes corbicular development in Apis mellifera. Biology Letters 10(1): 20131021

Metz H C (1996). Turkey: a Country Study. Federal Research Division of the Library of Congress, U.S. Government Printing Office, Washington, D.C pp. 175-176

Michener C D (1974). The social behavior of the bees: a comparative study (Vol. 73, No. 87379). Harvard University Press 7-22

Michener C D (2007). The Bees of the World, second edition. Baltimore: Johns Hopkins

Michener C D, Winston M L \& Jander R (1978). Pollen manipulation and related activities and structures in bees of the family Apidae. University of Kansas, Science Bulletin 51(19): 575-601

Mobus B (1972). The importance of propolis to the honey bee. British Bee Journal 19(8): 198-199

Ochi T (1981). A new method to collect propolis. Honey Bee Science 2(1): 16

Ruttner F (1988a). Biogeography and taxonomy of honey bees. Springer Verlag, Berlin pp. 165-256

Ruttner F (1988b). Breeding Tecnique and selection for Breeding of Honey bee. G. bread and Sons. Led. Brighton U.K

Silici S \& Kutluca S (2005). Chemical composition and antibacterial activity of propolis collected by three different races of honeybees in the same region. Journal of Ethnopharmacology 99: 69-73

Skorikov A S (1929). Eine neue Basis für eine Revision der Gattung Apis L. Reports on Applied Entomology 4: 249264

SPSS 15.0 (SPSS for Windows, Release 15.0) (2005). Standard Version, SPSS Inc., (www.SPSS.com.tr.)

Şahinler N \& Gül A (2005). The effects of propolis collecting methods and honey bee genotypes on propolis yield. Pakistan Journal of Biological Sciences 8(9): 1212-1214

Şahinler N \& Yücel B (2016). Biological activities and using facilities of Turkish propolis. Works of the Faculty of Agriculture and Food Sciences, University of Sarajevo 66(1): 82-85

Thorp R W (1979). Structural, behavioral, and physiological adaptations of bees (Apoidea) for collecting pollen. Annals of the Missouri Botanical Garden 66(4): 788-812

Thorp R W (2000). The collection of pollen by bees. Plant Systematics and Evolution 222: 211-223

Winston M L (1991). The biology of the honey bee. Harvard University press

Winston M L \& Michener C D (1977). Dual origin of highly social behavior among bees. Proceedings of the National Academy of Sciences 74(3): 1135-1137

Wollenweber E \& Buchmann S L (1997). Feral Honey Bees in the Sonoran Desert: Propolis Sources Other than Poplar (Populus spp.). Zeitschrift für Naturforschung C 52: 530-535 